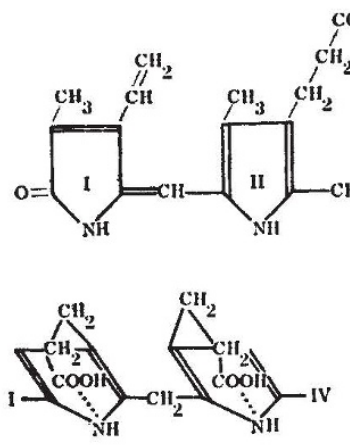

STR C T E R E 1 .

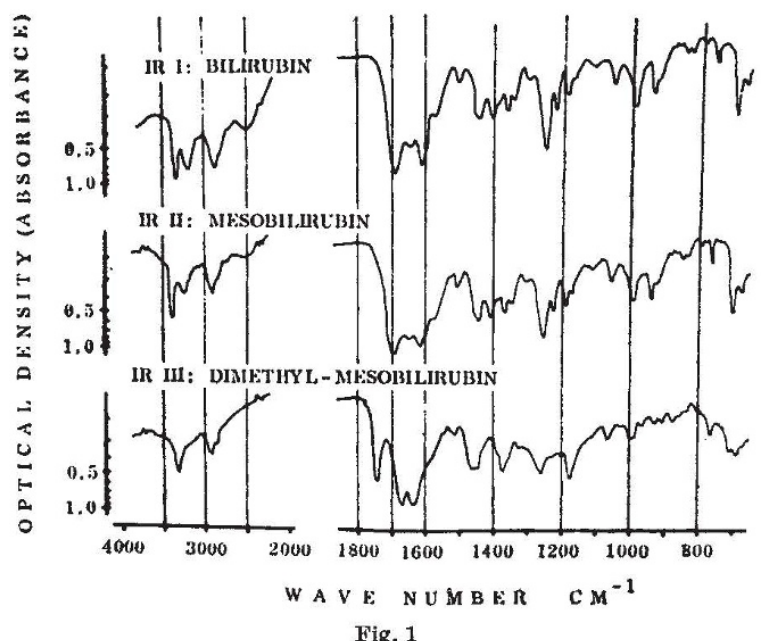

The 2,500-band present in the first two curves (Fig. 1, IR I and II) has disappeared in the ester-curve (Fig. 1, $I R$ III); therefore, this band is supposed to be due to carboxyl-OH, which consequently must have been displaced from $3,600 \mathrm{~cm}^{-1}$. The band registered at 1,680 (Fig. I, IR I and II) probably is the carboxyl $-\mathrm{C}=\mathrm{O}$ band usually found between 1,700 and $1,725 \mathrm{~cm}^{-1}$. The bands at 1,645 and $1,615 \mathrm{~cm}^{-1}$ in the first two curves (Fig. 1, $I R I$ and II) seem to be identical with the 1,670 and 1,635 bands in the third curve (Fig. 1, IR III). The 1,740 band is due to the ester-bond.

The displacements of infra-red bands obtained with the mesobilirubin-dimethylester towards higher wave numbers and of the infra-red bands of bilirubin and mesobilirubin towards lower wave numbers than expected seem to indicate that the carboxyl-groups in bilirubin (and mesobilirubin) are engaged in hydrogen bond formation.

The presence of intermolecular hydrogen bonds, however, cannot be excluded because the infra-red spectra were obtained in potassium bromide (solubility in organic solvents is too low). But, in so far as nuclear magnetic resonance spectra could be interpreted (a rather heavy background noise and weak signals due to low solubility), spectra of mesobilirubin and its dimethylester were significantly more different than due to esterification only.

The nuclear magnetic resonance spectra together with the infra-red spectra and the difference in reactability of bilirubin and its conjugates and the experience that di-esters are more reactive than mono-esters seem to indicate that intramolecular hydrogen bonds are present in the bilirubin molecule as indicated in Fig. 1.

Institute for Medical Biochemistry,

$$
\text { J. FoG }
$$

University of Oslo.

Institute of Aviation Medicine, Blindern, Oslo.

\section{Thiamine-sparing Action of Mustard and Role of Coprophagy}

THE presence of crucifer material in the diet is reported to increase the urinary and fæcal excretion of thiamine with greater storage of the vitamin in viscera of rats ${ }^{1}$. We have also reported that 2 per cent mustard (Brassica nigra) replacing the same weight of sucrose in the thiamine. free diet enhanced the synthesis of thiamine in rats only when coprophagy was allowed ${ }^{2}$. The coliform count in the cæca of mustard-fed rats was also found to increase considerably. The question then arises whether the vita. min was absorbed in the gut immediately after synthesis or whether it was excreted in the frees and was available only after the animal had eaten its fæces.

Therefore, the investigation reported here was undertaken to examine the effect of prevention of coprophagy on the thiamine-sparing action of mustard. For this purpose eighteen male weanling albino rats were fed the same thiamine-free basal diet used by us in previous experiments ${ }^{2}$. Mustard was given in the form of aqueous extract ( $100 \mathrm{mg} / \mathrm{rat})$ daily along with the diet and animals were fed ad lib. The rats were divided into three groups and were caged individually. In one group coprophagy was prevented by a recently published technique ${ }^{3}$; in the second group the fæces of each rat were collected and re-fed daily; in the third group coprophagy was not prevented.

The animals were weighed weekly and after 6 weeks they were killed. The thiamine content of liver, heart and cæcum was estimated by the thiochrome method.

It was observed that the rats which were re-fed with their fæces showed the highest growth throughout the experiment and tissue thiamine content of these animals was also much higher, whereas those which were prevented from eating their fæees became reduced in weight and showed symptoms of thiamine deficiency, such as polyneuritis and loss of appetite during the experiment. However, the rats which were allowed to eat their fæces (coprophagy not prevented) recorded a steady growth and their tissue thiamine content was also higher than that of group 1 ('Table I).

\begin{tabular}{|c|c|c|c|c|c|}
\hline \multirow{4}{*}{$\begin{array}{c}\text { Group } \\
1 \\
2 \\
3\end{array}$} & $\begin{array}{l}\text { GAIN IN BODY } \\
\text { Experimental } \\
\text { conditions }\end{array}$ & $\begin{array}{l}\text { Liver } \\
\text { thiamine } \\
(\mu \mathrm{g} / \mathrm{g})\end{array}$ & $\begin{array}{l}\text { Heart } \\
\text { thiamine } \\
(\mu \mathrm{g} / \mathrm{g})\end{array}$ & $\begin{array}{l}\text { Crcal } \\
\text { thiamine * } \\
\langle(\mu \mathrm{g} / \mathrm{g})\end{array}$ & $\begin{array}{c}\text { Total gain in } \\
\text { body-weight } \\
\text { (g) }\end{array}$ \\
\hline & $\begin{array}{c}\text { opropnagy } \\
\text { prevented }\end{array}$ & 0.55 & $1 \cdot 06$ & $0 \cdot 76$ & 7 \\
\hline & Fæces re-fed & $2 \cdot 51$ & $2 \cdot 79$ & $3 \cdot 16$ & 148 \\
\hline & allowed & $1 \cdot 13$ & $1 \cdot 33$ & $2 \cdot 01$ & 105 \\
\hline
\end{tabular}

These findings indicate that the thiamine-sparing action of mustard is abolished when coprophagy is prevented, while those eating their own fæces showed higher tissue thiamine content. Similar observations were reported by Morgan and Yudkin ${ }^{4}$ regarding the thiamine-sparing action of sorbitol. From these and previous results, it is suggested that coprophagy plays two different parts. First the thiamine present in the fæces might be absorbed when the latter are eaten by the animals, and secondly coprophagy might also cause a change in the intestinal flora which has been found to be favourable for the synthesis of thiamine ${ }^{5}$.

\section{S. K. MEghaL *}

Department of Biochemistry,

$$
\text { M. C. NATH }
$$

University of Nagpur, India.

* Government of India, senior research training scholar.

${ }^{1}$ Sato, Z., Vitamins (Japan), 5, 184 (1952).

2 Meghal, S. K., and Nath, M. C., Ann. Biochem. Exp. Med. (India), 22, 99 (1962).

${ }^{3}$ Barnes, R. H., Fiala, G., MoGehee, B., and Brown, A., J. Nutrition, 63, 489 (1957).

" Morgan, T. B., and Yudkin, J., Nature, 184, 909 (1959).

s Nath, M. C., and Meghal, S. K., Biochem. J., 81, 220 (1961). 